\title{
Soybean Yield, Soil Porosity and Soil Penetration Resistance under Mechanical Scarification in No-Tillage System
}

\author{
Edleusa Pereira Seidel ${ }^{1}$, Ana Paula Heck Schneider ${ }^{1}$, Monica Carolina Sustakowski ${ }^{1}$, Lucas Murakami Matté ${ }^{1}$, \\ Marcos Cesar Mottin ${ }^{1} \&$ João Henrique Silva ${ }^{1}$ \\ ${ }^{1}$ Western Paraná State University, PR, Brazil \\ Correspondence: Edleusa Pereira Seidel, Western Paraná State University, PR, Brazil. E-mail: \\ edleusa.seidel@unioeste.br
}

Received: December 15, 2017

Accepted: February 13, $2018 \quad$ Online Published: March 15, 2018

doi:10.5539/jas.v10n4p268

URL: https://doi.org/10.5539/jas.v10n4p268

\begin{abstract}
Technological development has triggered a steady increase in Brazilian agricultural production, but also brought problems due to the excessive land use. The lack of care with proper management practices has led to soil physical degradation, mainly the formation of impermeable layers, which can lead to a reverse effect, a reduction in crop yield. It can be potentiated in silage production and with the lack of cover crops. To minimize the negative impacts of soil compaction, scarification is recommended, but its effectiveness has been questioned in no-tillage system. Thus, an experimental field was implemented in Brazil in 2015-2016 season, to evaluate the mechanical scarification on soybean production in succession to silage and grain corn intercropped with Brachiaria (Urochloa ruziziensis) as well as the physical properties of the soil. The experimental layout was a complete randomized block design with four replications. The plots were composed of second crop maize (autumn) intercropped with brachiaria, in two systems: silage and dry grains. The subplots were composed of three management system: no-tillage, reduced tillage cultivation with Terrus scarifier and Fox scarifier. Corn harvesting systems as well the scarifiers use did not affect soybean production and its yield components. The use of scarifiers reduced soil coverage, plant population, and soil penetration resistance. The data suggest that there was no persistence in the benefits presented by scarification. Soybean was able to break through the compacted layers, even above the critical level, corroborating with the hypothesis that the use of scarifiers does not bring benefits in no-tillage system.
\end{abstract}

Keywords: corn silage and grain, cover crop, soil porosity, soil compaction, sustainable management, no-tillage

\section{Introduction}

Currently, about $6 \%$ (64 million ha) of the Brasilian territory is destined to the production of grains, especially soybean (Scolari, 2006), and the country has became the second largest producer of grains in the world. In the 2014/2015 harvest, production reached approximately 96 million tons (CONAB, 2015).

The increasing production growth and the technological evolution of the agricultural sector underwent major transformations. Originally, conventional soil preparation practices cause excessive physical soil degradation, as well as the formation of compacted layers, thus resulting in low agricultural productivity (Silva, 2007; Marahatta, Sah, Mac Donald, Timilnisa, \& Devkota, 2014). According to Debiasi, Levien, and Trein (2010), the formation of compacted layers in the soil has been considered as the main factor responsible for the reduction of crop productivity; since it changes the physical-water properties in the radicular environment. Compressing reduces the availability of water and oxygen (Millington, Misiewicz, Dickin, White, \& Godwin, 2016). It also increases soil resistance, preventing root growth, which limits the depth and volume of the soil explored by the roots (Cavalieri, Tormena, Vidigal Filho, Gonçalves, \& Costa, 2006). Among the physical attributes with potential for the spatial detection of soil compaction, we have the evaluation of porosity, soil density and resistance to penetration (RP).

Soil compaction at elevated levels is a difficult reversal process, especially in clay soils (Girardello et al., 2011). There are many strategies for reducing soil compaction and for breaking-up compact layers. We can mention consortiums between cultures, crop-livestock integration, and green manure. 
Cultivation systems, involving crops and forages, especially brachyria, represent an excellent alternative for maize in a no-tillage system. This consortium drew attention to its potential benefits to the no-tillage system, mainly because grasses have a more aggressive development, a high potential of phytometry production, with high $\mathrm{C} / \mathrm{N}$ ratio, guaranteeing soil cover for a longer time (Borghi, Crusciol, Costa, \& Mateus, 2006). The inclusion of forage in grain systems alters the physical and chemical properties of the soil, increases the presence of straw and roots that contribute to the increase of soil carbon content and the stability of aggregates and macroporosity (Seidel, Gerhard, Castangara, \& Neres, 2014), leading to a higher infiltration of water in the soil (Loss, Pereira, Giácomo, Perin, \& Anjos, 2011).

Another option is soil scarification, which favors the root development of the plants, increases the surface roughness, raises infiltration rate, increasing the water storage capacity in the soil, which in turn results in a greater availability of water to the crops. It also results in increased macro porosity and decreased soil density (Ferreras, Battista, Ausilio, \& Pecorari, 2001; Camara \& Klein, 2005).

Scarification, according to Camara (2004), is classified as a conservationist soil preparation by revolving it just a little, breaking its points of resistance, thus leaving the maximum of residues on the surface, in addition to increasing the structural stability and soil permeability, and reducing the risks of water erosion. However, the efficiency of this practice in increasing soybean crop productivity has been contradictory. D. Secco, Ros, J. K. Secco, and Fiorin (2005), in their research with scarifiers in soybean crops under the no-tillage system did not observe a significant difference in productivity.

This work hypothesized that, in soil conservation systems, such as no-tillage system, there is a possibility of soil recovery without mechanized interventions, even in compacted soils, and its objective was to evaluate the effect of scarification after harvesting of autumn maize, both as dry grains and silages, on the percentage of soil cover, soil physical properties and on soya production components in succession.

\section{Method}

\subsection{Description of the Experimental Area and Experimental Design}

The works were developed in the municipality of Quatro Pontes, in the latitude geographical coordinates $24^{\circ} 32^{\prime} 51.23^{\prime \prime} \mathrm{S}$ and longitude coordinates $53^{\circ} 57^{\prime} 57.78^{\prime \prime} \mathrm{W}$, and average altitude of 412 meters.

The climate of the region is classified as Cfa, mesotherm subtropical humid according to Köppen's climatic classification, with hot summers with a tendency for rainfall concentration (average temperature higher than $22{ }^{\circ} \mathrm{C}$ ), winters with infrequent frost (average temperature below $18{ }^{\circ} \mathrm{C}$ ), without defined seasons. The average annual rainfall is around $1,500 \mathrm{~mm}$. The soil was classified as Eutrophric Red Latosol, with a very clayey texture (Santos et al., 2006).

The experimental design was a randomized block design with four replications in a subdivided plot scheme. The main plot consisted of second crop maize in consortium with Brachiaria ruzuziensis in two harvest systems: silage and dry grains. The subplots were composed of three management system: no-tillage, reduced tillage cultivation with Terrus scarifier and Fox scarifier. Each experimental unit was $5 \mathrm{~m}$ wide and $10 \mathrm{~m}$ long, constituting an area of $50 \mathrm{~m}^{2}$ per plot.

\subsection{Management and Cropping Systems}

The maize crop was mechanically sown. Morgan hybrid 30A37 was used at $0.70 \mathrm{~m}$ spacing with a population of $68,000 \mathrm{ha}^{-1}$ plants. Sowing fertilization was performed with $330 \mathrm{~kg} \mathrm{ha}^{-1}$ of the formulation 10-24-16 $\left(\mathrm{N}-\mathrm{P}_{2} \mathrm{O}_{5}-\mathrm{K}_{2} \mathrm{O}\right)$. When the maize was with 4-7 leaves, was applied in topdressing $100 \mathrm{~kg} \mathrm{ha}^{-1}$ of nitrogen on the soil surface in the form of urea.

Scarification of the area was carried out one week after the maize harvest. The Terrus scarifier had 7 rods, with rod spacing of $65 \mathrm{~cm}$ and working depth between 0.30 and $0.35 \mathrm{~m}$. The Fox scarifier has 5 stems with a distance between stems of $0.50 \mathrm{~m}$ and working depth between 0.18 and $0.26 \mathrm{~m}$.

On September 16th, 2015 soybean was sown using a direct, no-tillage Tatu Ultra Flex seeder with $0.45 \mathrm{~m}$ spacing and equipped with a transverse fertilizer distributor. The area was fertilized with $372 \mathrm{~kg} \mathrm{ha}^{-1}$ of NPK in the commercial formula 6-36-6, and $4 \mathrm{~kg}$ of potassium chloride in coverage. Harvesting was done manually, 129 days after sowing.

Thirty days after emergence, the plant population was evaluated by counting the number of plants over 8 meter in the four central lines of each subplot. The vegetative cover was also evaluated using the tagged tread method. In an extension of 11.5 meter, the track was extended diagonally to the subplot, and the points with uncovered soil were counted in intervals of 0.10 meter, thus determining the percentage without soil coverage. 
To determine the components of soybean production, 10 plants were randomly collected per subplot. In order to determine the height of the plants was used a measuring tape, taking the level of the ground to the last insertion of trefoil as parameter. The number of pods and the number of grains per plants were determined by counting, while the mass of one thousand grains was estimated by weighing eight subsamples of 100 grains per plot on a precision scale. For the evaluation of crop yield, each plot was collected, discarding the borders, and the weight determined on a scale with the results expressed in $\mathrm{kg} \mathrm{ha}^{-1}$.

\subsection{Determination of Porosity, Soil Density and Soil Penetration Resistance}

After the soybean harvest, undisturbed samples were collected through a metal cylinder (Kopecky ring) of known internal volume at the depths of 0.0 to $0.05 ; 0.05 \mathrm{~m}$ to 0.1 and 0.1 to 0.15 meter. The set was weighed after saturation of the samples for 24 hours and placed in a tension table $(0.006 \mathrm{MPa})$ for determination of the macroporosity. After, the samples were placed in aluminum cans, and dried in an oven with forced air circulation at $105^{\circ} \mathrm{C}$ until constant weight, for determination of microporosity, and soil bulk density.

In order to evaluate soil resistance to penetration, an impact penetrometer was used. The impact weight in free fall reached $0.40 \mathrm{~m}$. The impact results in $\mathrm{dm}^{-1}$ were converted into impact on soil dynamic resistance (Mpa) through equation of Stolf (1991): $\mathrm{RP}=5.6+6.89 \mathrm{~N}$, where: $\mathrm{RP}=$ Resistance to penetration in $\mathrm{kgf} \mathrm{cm}^{-2} ; \mathrm{N}=$ penetration in impact results in $\mathrm{dm}^{-1}$. For conversion of $\mathrm{RP}$ in $\mathrm{kgf} \mathrm{cm}^{-2}$ to $\mathrm{MPa}$, the result obtained in equation 1 was multiplied by constant 0.0981 .

The results of the evaluated parameters were submitted to analysis of variance by the SISVAR computer program, and the averages were submitted to the Tukey test for the comparison of multiple averages, at 5\%.

\section{Results and Discussion}

\subsection{Soil Cover, Production Components and Soybean Yield}

Statistical analysis showed that there was an isolated significant effect $(\mathrm{P}<0.05)$ for the studied factors, and there was no effect for the interaction. The two corn harvest systems: silage and dry grains, promoted significant differences in the percentage of soil coverage with straw. In the area where the corn intercropped with brachiaria was intended for silage, the coverage of the soil with straw was $63 \%$. On the other hand, in the area destined to the production of dry grains, coverage of the soil with straw was $74 \%$; an increase in soil coverage by $17 \%$ (Table 1).

A lower coverage of the area destined to silage production was expected, because in the silage system it is necessary to harvest the aerial part of the plant, so that the percentage of cultural remains that stay in the ground is reduced. This reduction in coverage could be even lower if maize was not intercropped with brachiaria.

The two systems of corn intercropped with brachiaria for silage and dry grains did not influence the soybean population, plant height, number of pods, grains per plant, the weight of a thousand grains or soybean yield in succession. The yield of the soybean after intercropping of maize with brachiaria harvested as dry grains and silage was $4,144 \mathrm{~kg} \mathrm{ha}^{-1}$ and 3,624 kg ha ${ }^{-1}$ respectively. There was a productivity difference of $490 \mathrm{~kg} \mathrm{ha}^{-1}$, but they were statistically the same.

\subsection{Physical Soil Properties}

There was interaction between cropping systems and soil management systems for macroporosity; and an isolated effect of scarification and no-tillage management for microporosity and total porosity at depth (Table 3 ).

At the depth of 0 to $0.05 \mathrm{~m}$ in the area where corn was harvested for silage or grains, there was a significant difference $(\mathrm{P}<0.05)$ for macroporosity. 
Table 1. Effect of the harvest system of the maize on the soybean's production components

\begin{tabular}{lllll}
\hline Harvest system & Soil coverage $(\%)$ & $\begin{array}{l}\text { Plant population } \\
\left(\text { plants ha }{ }^{-1}\right)\end{array}$ & Plant height $(\mathrm{cm})$ & Pods per plant \\
\hline Silage & $63 \mathrm{~b}$ & $316.898^{\mathrm{ns}}$ & $79.60^{\mathrm{ns}}$ & $39.42^{\mathrm{ns}}$ \\
Dry grains & $74 \mathrm{a}$ & 310.893 & 79.36 & 45.96 \\
LSD & 4.70 & 10.971 & 3.52 & 6.76 \\
\hline Harvest system & Grains per plant & Weight of 1.000 grains & ${\text { Yield }\left(\mathrm{kg} \mathrm{ha}^{-1}\right)}$ \\
\hline Silage & $92.62^{\mathrm{ns}}$ & $171^{\mathrm{ns}}$ & $3.624^{\mathrm{ns}}$ \\
Dry grains & 108.97 & 169 & 4.114 \\
LSD & 18.05 & 17.05 & 868.19 & \\
\hline
\end{tabular}

Note. Averages followed by distinct letters, in the same column, differ by the Tukey test $(\mathrm{P}<0.05)$.

When the soil management systems were evaluated, there was statistical difference for percentage of soil coverage and plant population. The highest soil coverage with straw was observed in the no-tillage system, with $79 \%$ of area covered. Meanwhile, in the treatments with scarifiers, the average coverage was $63 \%$. There was a reduction in soil cover by $16 \%$ (Table 2 ).

Table 2. Yield contributing characters of soybean as affected by no-tillage and reduced tillage cultivation

\begin{tabular}{|c|c|c|c|c|}
\hline Soil management & Soil coverage $(\%)$ & 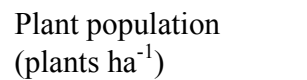 & Plant height $(\mathrm{cm})$ & Pods per plant \\
\hline No-tillage & $79 \mathrm{a}$ & $330,749 \mathrm{a}$ & $81.99^{\mathrm{ns}}$ & $40.92^{\mathrm{ns}}$ \\
\hline Terrus scarifier & $64 \mathrm{~b}$ & $311,458 \mathrm{~b}$ & 78.61 & 42.17 \\
\hline Fox scarifier & $62 \mathrm{~b}$ & $299,479 b$ & 77.85 & 44.97 \\
\hline LSD & 4.70 & 10,971 & 3.52 & 6.76 \\
\hline Soil management & Grains per plant & $\begin{array}{l}\text { Weight of } 1.000 \text { grains } \\
\text { (g) }\end{array}$ & Yield (kg ha $\left.{ }^{-1}\right)$ & \\
\hline No-tillage & $94.56^{\mathrm{ns}}$ & $179.11^{\mathrm{ns}}$ & $4.000^{\mathrm{ns}}$ & \\
\hline Terrus scarifier & 100.51 & 164.98 & 3.711 & \\
\hline Fox scarifier & 107.31 & 165.68 & 3.896 & \\
\hline LSD & 18.05 & 17.05 & 868.19 & \\
\hline
\end{tabular}

Note. $\mathrm{ns}=$ not significant. Averages followed by distinct letters, in the same column, differ by the Tukey test $(\mathrm{P}$ $=.05)$.

According to Cruz et al. (2017), for the requirements of no-tillage to be met, the cultural remains must cover at least $80 \%$ of the soil surface or maintain $6 \mathrm{tha}^{-1}$ of dry matter; it should be noted that the evaluation conducted in this experiment was performed 30 days after sowing.

When evaluating the management systems (no-tillage and reduced tillage cultivation with Fox and Terrus scarifier), there was no significant effect of the management systems on plant height, number of pods per plant, number of grains per plant and mass of one thousand grains. Nevertheless, there was an effect over the plant population. No-till showed the largest population of plants with 330.749 plants per hectare, while the area in which the scarifier was used had 311.458 plants per hectare. The reduction of the plant population in scarified areas of 5.8\%, probably associated with less contact between soil and seed during sowing; or due to variation in soil temperature, which was more exposed to the incidence of solar rays, and consequently may have affected soil moisture. This particular reduction in the plant population also allowed it to remain within the recommended range of 300.000 plants $^{-1}{ }^{-1}$ Garcia, Pipolo, Lopes, \& Portugual, 2007); however, this did not affect soybean yield.

The soybean yield was $3.869 \mathrm{~kg} \mathrm{ha}^{-1}, 23 \%$ higher than the local average yield in the respective harvest (CONAB, 2016). The data demonstrated that the use of mechanical scarifiers, when compared to no-tillage did not alter soybean productivity. This result can be corroborated by Girardello et al. (2014), who did not find an increase in soybean yield due to mechanical scarification. The authors have justified this absence with the rustic 
characteristics of the soybean, under favorable climatic conditions. Contrariwise, Kunz et al. (2013), observed a reduction in the soybean yield with the use of scarifiers when the physical-water conditions of the soil were less favorable to the development of the plant.

The maintenance of crop residues on the soil it is essential for the maintenance of the no-tillage system in tropical regions. This practice allows an accumulation of organic matter on the soil surface, protecting the soil from erosive agents. The soil organic carbon is considered a key property in soil quality because it influences soil biota dynamics and acts on many soil physical and chemical functions (Albuquerque et al., 2005; Cherubin et al., 2016).

Temperate regions are more susceptible to temporal variations (Bottineli et al., 2017) but tropical ones, are very sensitive to the maintenance of organic matter in the system. In the superficial layer, where the straw is invariably concentrated and the machines operate, it tends to have a greater macroporosity, and the reverse occurs in depth, where the tire pressure and the weight of the machines result in compaction or densification over time (Secco et al., 2005). This problem is aggravated in silage production due to the non-deposition of straw on the surface, which serves as a buffer for the action of agricultural machinery besides promoting the biological activity of the soil.

In corn harvested for silage there was no effect between the use of scarifiers and no-tillage; however, in corn harvested for grain, higher macroporosity $\left(0.082 \mathrm{~m}^{3} \mathrm{~m}^{-3}\right)$ was observed when the Terrus scarifier was used (Table $3)$. When we analyzed the management systems, greater macroporosity was observed when the corn was harvested as grains and when it was managed with the Terrus scarifier, and there was no difference between no-tillage and Fox scarifier. Differential behavior was observed in the depth of 0.05 to $0.10 \mathrm{~m}$, in the area where corn was harvested for silage. The use of the Terrus scarifier promoted greater macroporosity and total porosity in relation to the other soil management; this is explained because this scarifier has winged tips, and allowed greater soil movement (Table 2).

The use of furrow stems can increase the roughness, decrease the density, increase the porosity and break the compacted layers of the soil in direct sowing, without totally compromising the system, since it does not revolve the soil and allow the straw to remain on the soil surface. This would lead to an improvement in the direct seeding system by increasing soil water infiltration and aeration, allowing adequate root growth in depth. In this way, positive results can be achieved with the use of furrow stems (Camera \& Klein, 2005; Bavoso, Giarola, Tormena, \& Pauletti., 2010; Melo, Nóbrega, Gnoatto, Marchetti, \& Lenz, 2014), justifying the results obtained with the Terrus scarifier, possibly more pronounced under conditions of greater compaction, as a function of silage production. However, in the same way, many studies have shown that the use of furrow stems does not present results that would justify its use. This would be because its effects would not be persistent, occurring the reconsolidation of the soil in a few months and leading to small gains or even losses of production (Secco et al., 2005; Reichert, Kaiser, Reinert, \& Riquelme, 2009a; Debiasi et al., 2009), which would also justify the results presented by the Fox scarifier.

There was difference $(\mathrm{P}<0.05)$ to soil resistance penetration. When the corn was harvested for silage the soil penetration resistance was higher until 0.12 meter; because in this system the traffic of machines is higher. The soil penetration resistance evaluated was higher than $3.0 \mathrm{Mpa}$, and it was considered a value above the critical level of 2.27 Mpa (Beutler, N. A. Centurion, J. F. Centurion, \& Silva, 2006; Freddi, Centurion, Duarte, \& Leonel, 2009). 
Table 3. Physical properties of soil after cultivation intercropped corn crop with silage and dry grains and soybean

\begin{tabular}{|c|c|c|c|c|c|c|c|c|}
\hline \multirow{2}{*}{ Soil Management } & \multicolumn{2}{|c|}{ Macroporosity } & \multicolumn{2}{|c|}{ Microporosity } & \multicolumn{2}{|c|}{ Total Porosity } & \multicolumn{2}{|c|}{ Density } \\
\hline & Silage & Grains & Silage & Grains & Silage & Grains & Silage & Grains \\
\hline & \multicolumn{6}{|c|}{ 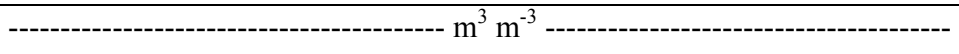 } & \multicolumn{2}{|c|}{---- $\mathrm{Mg} \mathrm{m}^{-3}$} \\
\hline \multicolumn{9}{|c|}{ ( } \\
\hline SPD & $0.049 \mathrm{Ba}$ & $0.056 \mathrm{Ab}$ & $0.45^{\mathrm{ns}}$ & $0.46^{\mathrm{ns}}$ & $0.499^{\mathrm{ns}}$ & $0.516^{\mathrm{ns}}$ & $1.41^{\mathrm{ns}}$ & $1.31^{\mathrm{ns}}$ \\
\hline Fox & $0.053 \mathrm{Aa}$ & $0.046 \mathrm{Ab}$ & 0.44 & 0.47 & 0.496 & 0.516 & 1.40 & 1.40 \\
\hline Terrus & $0.062 \mathrm{Ba}$ & $0.082 \mathrm{Aa}$ & 0.46 & 0.46 & 0.521 & 0.542 & 1.40 & 1.34 \\
\hline CV $(\%)$ & 14.47 & 24.64 & 7.42 & 5.98 & 8.22 & 9.59 & 5.66 & 8.14 \\
\hline \multicolumn{9}{|l|}{$0.05-0.1 \mathrm{~m}$} \\
\hline SPD & $0.025 \mathrm{Ab}$ & $0.029 \mathrm{Aa}$ & $0.44^{\mathrm{ns}}$ & $0.45^{\mathrm{ns}}$ & $0.465^{\mathrm{ns}}$ & $0.479 \mathrm{~ns}$ & $1.51^{\mathrm{ns}}$ & $1.51^{\mathrm{ns}}$ \\
\hline Fox & $0.024 \mathrm{Bb}$ & $0.036 \mathrm{Aa}$ & 0.43 & 0.45 & 0.454 & 0.486 & 1.50 & 1.50 \\
\hline Terrus & $0.037 \mathrm{Aa}$ & $0.027 \mathrm{Ba}$ & 0.46 & 0.46 & 0.497 & 0.487 & 1.49 & 1.47 \\
\hline CV (\%) & 17.82 & 12.16 & 5.32 & 4.88 & 5.56 & 4.79 & 5.92 & 3.66 \\
\hline \multicolumn{9}{|l|}{$0.1-0.15 \mathrm{~m}$} \\
\hline SPD & $0.032^{\mathrm{ns}}$ & $0.030^{\mathrm{ns}}$ & $0.45^{\mathrm{ns}}$ & $0.44 b$ & $0.482^{\mathrm{ns}}$ & $0.470 \mathrm{~b}$ & $1.49^{\mathrm{ns}}$ & $1.55^{\mathrm{ns}}$ \\
\hline Fox & 0.025 & 0.031 & 0.45 & $0.43 b$ & 0.475 & $0.461 \mathrm{~b}$ & 1.51 & 1.40 \\
\hline Terrus & 0.029 & 0.027 & 0.45 & $0.47 \mathrm{a}$ & 0.479 & $0.497 \mathrm{a}$ & 1.52 & 1.43 \\
\hline CV\% & 13.12 & 14.49 & 3.61 & 5.63 & 2.68 & 4.87 & 5.23 & 4.06 \\
\hline
\end{tabular}

Note. Averages followed by lower case letters in the column and upper case in the row in each layer, do not differ by Tukey test $(\mathrm{P}<0.05)$. CV $=$ Coefficient of Variation.

however, it did not reduce soybean productivity (Figure 1a) demonstrating that soybean roots were capable of breaking up compacted layers. These results corroborate those presented by Secco et al. (2005), Reichert et al. (2009a) and Debiasi et al. (2010), demonstrating that the effects caused by furrow rods were ephemeral.

In the mechanical management of the soil (Figure 1b), there was a statistical difference between the soil management systems. Higher soil resistance penetration (4.0 MPa) was observed in the no-tillage, at depth of 0.10 to $0.20 \mathrm{~m}$, and there was no significant difference for the management with the Fox and Terrus scarifiers.

This result was also expected, because in the no-tillage there is no stirring of the soil and are the main concern about the non-tillage system. 
(a)

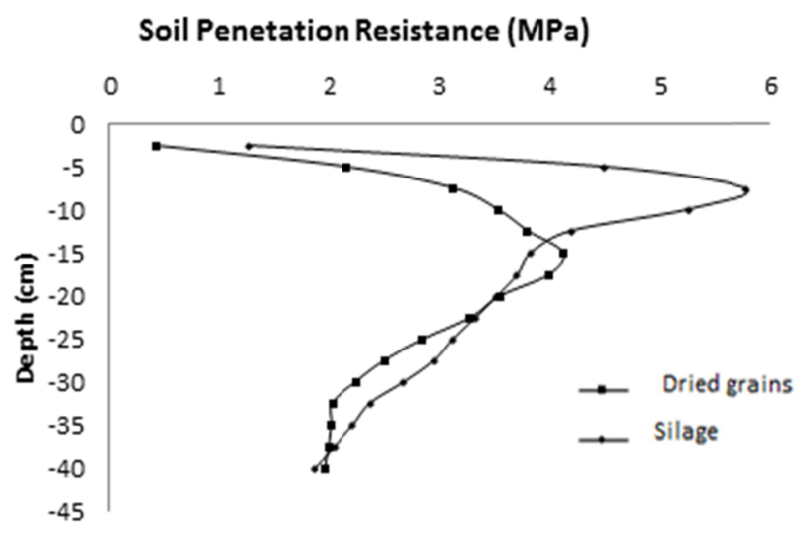

(b)

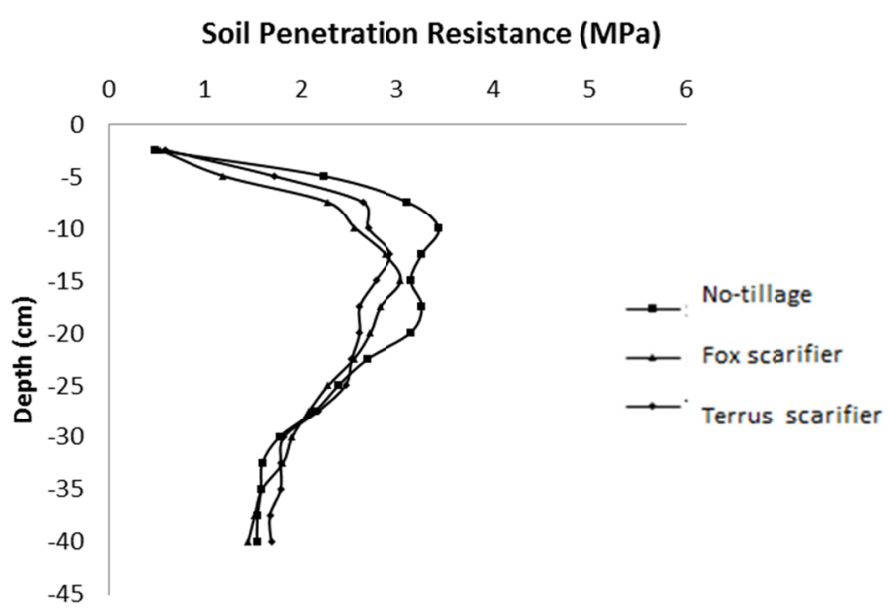

Figure 1. Soil resistance to penetration, in the depth of 0 to $0.40 \mathrm{~m}$, in no-tillage, and reduced cultivation with scarifier

Penetration resistance values greater than $2 \mathrm{MPa}$, with different variation between different textural classes, are considered limiting to the root development of cultures (Silva, Tormena, Junior, Imhoff, \& Klein, 2016; Reichert, Suzuki, Reinert, Horn, \& Hakansson, 2009b). Freddi et al. (2009) observed a positive correlation between depth and soil compaction, manifested in both soil density, maroporosity and resistance to penetration. In this sense, Freddi et al. (2009) observed that different levels of compaction interfered in the grain yield of the hybrids after a resistance of 2.15 MPa. Rosset (2015) observed RP of 2.09 MPa for no-till systems with 22 years of implantation. This evidences the presence of compacted layers in subsurface, which can cause development impediment to the root system of the cultures, with consequent restriction in the production in prolonged water stresses. However, the joint evaluation of different works indicates that, in soils under no-tillage system (SPD), the critical value seems to be higher (Reichert et al., 2009b). Although the critical limit may be greater than the theoretical limit, it is evident that soil compaction has been the most challenging problem currently encountered in commercial crops in the direct crop management system.

Voorthees, Johnson, Randall, and Nelson (1989) studied compacted soils on the surface and subsoil and found that compaction interfered in maize crop production, but this variation was related to the variation of climatic conditions, indicating that in some conditions, higher soil density may not be detrimental to culture. Different root systems have different actions on the soil. Mottin (2016) found that treatments with grasses (oats and brachiaria) allowed a lower penetration resistance compared to treatments with legumes (lupine and pea) up to a depth of $20 \mathrm{~cm}$. The results showed that an increase in the production of organic material influences RP. 
The management of corn for silage and the use of scarifiers did not influence the components of soy production. The use of scarifiers decreased soil cover and the population of soybean crop plants. Even though the use of scarifiers has influenced soil porosity and resistance to penetration, this did not translate into yield gains for soybean cultivation, which allows saying that soybean was able to break down the compacted soil layer even above the values considered critical by literature. It can be inferred that the critical values pointed out by the older works may be overestimated for the no-tillage system.

\section{References}

Bavoso, M. A., Giarola, N. F. B., Tormena, C. A., \& Pauletti, V. (2010). Preparo do solo em áreas de produção de grãos, silagem e pastejo: Efeito na resistência tênsil e friabilidade de agregados. Rev. Bras. Ci. Solo, 34, 227-234. https://doi.org/10.1590/S0100-06832010000100023

Beutler, N. A., Centurion, J. F., Centurion, M. A. P. C., \& Silva, A. P. (2006). Effect of compaction on yield of soybean cultivars on red latosol. Brazilian Journal of Soil Science, 30, 787-794. https://doi.org/10.1590/ S0100-06832011000500012

Borghi, E., Costa, N. V., Crusciol, C. A. C., \& Mateus, G. P. (2008). Influência da distribuição espacial do milho e da Brachiaria brizantha consorciados sobre a população de plantas daninhas em sistema de plantio direto na palha. Planta Daninha, 26(3), 559-568. https://doi.org/10.1590/S0100-83582008000300011

Camara, R. K. (2004). Influence of soil scarification under no-tillage system on soil properties and soybean crop (Masters dissertation, postgraduate program in plant production, University of Passo Fundo, Passo Fundo, $\mathrm{RS}$, Brasil).

Camara, R. K., \& Klein, V. A. (2005). Chiseling in no-tillage system as soil and water conservation practice. Brazilian Journal of Soil Science, 29, 789-796. https://doi.org/10.1590/S0100-06832005000500014

Cavalieri, K. M. V., Tormena, C. A., Vidigal Filho, P. S. V., Gonçalves, A. C. A., \& Costa, A. C. S. (2006). Effects of preparation systems on the physical properties of a dystrophic Red Latosol. Brazilian Journal of Soil Science, 30, 137-147. Retrive from http://www.scielo.br/readcube/epdf.php?doi=10.1590/S0100-0683 2006000100014\&pid=S0100-06832006000100014\&pdf_path=rbcs/v30n1/a14v30n1.pdf\&lang=pt

Cherubin, M. R., Karlen, D. L., Franco, A. L. C., Cerri, C. E. P., Tormena, C. A., \& Cerri, C. C. A. (2016). Soil Management Assessment Framework (SMAF) evaluation of Brazilian sugarcane expansion on soil quality. Soil Sci Soc Am J, 80, 215-226. https://doi.org/10.2136/sssaj2015.09.0328

CONAB. (2015). Follow-up of the Brazilian crop of grain harvests 2014/2015 (Vol. 2, No. 9, p. 79). CONAB, Brasília.

Cruz, J. C., Alvarenga, R. C., Viana, J. H. M., Pereira Filho, I. A., Albuquerque Filho, M. R., \& Santana, D. P. (2017). Manejo da cultura do milho em sistema de plantio direto. Retrive from https://www.embrapa.br/.../ manejo-da-cultura-do-milho-em-sistema-plantio-direto

Debiasi, H., Levien, R., \& Trein, C. R. (2010). Soybean and corn yield after soil winter covers and soil mechanical loosening. Brazilian Agricultural Research, 45, 603-612. https://doi.org/10.1590/S0100-204 X2010000600010

Ferreras, L. A., Battista, J. J., Ausilio, A., \& Pecorari, C. (2001). Physical parameters of the soil in undisturbed conditions and under tillage. Brazilian Agricultural Research, 36, 161-170.

Freddi, O. S., Centurion, J. F., Duarte, A. P., \& Leonel, P. L. (2009). Compactação do solo e produção de cultivares de milho em latossolo vermelho. I-características de planta, solo e índices. Rev. Bras. Ci. Solo, 33, 793-803. https://doi.org/10.1590/S0100-06832009000400005

Garcia, A., Pipolo, A. E., Lopes, I. O. N., \& Portugal, F. A. F. (2007). Instalação da lavoura de soja: época, cultivares, espaçamento e população de plantas. Circular Técnica (Vol. 51, pp. 7-9). Londrina: EMBRAPA.

Girardello, V. C., Amado, T. J. C., \& Nicoloso, R. S. (2011). Changes in the physical attributes of a red latosol under no-tillage induced by different types of scarifiers and the yield of soybean. Brazilian Journal of Soil Science, 35, 2115-2126. https://doi.org/10.1590/S0100-06832011000600026

Girardello, V. C., Amado, T. J. C., Santi, A. L., Cherubin, M. R., Kunz, J., \& Teixeira, T. G. (2014). Resistance to penetration, efficiency of mechanical scarifiers and soybean yield in clayey latosol managed under long-term no-tillage. Brazilian Journal of Soil Science, 38, 1234-1244. https://doi.org/10.1590/S010006832014000400020 
Kemper, W. D., \& Chepil, W. S. (1965). Size distribution of aggregates. In C. A. Black, D. D. Evans, J. L. White, L. E. Esminger, \& F. E. Clark (Eds.), Methods of soil analysis-Physical and mineralogical properties, including statistics of measurement and sampling. Madison.

Kunz, M., Gonçalves, A. D. M., Reichert, J. M., Guimarães, R. M. L., Reinert, D. J., \& Rodrigues, M. F. (2013). Soil compaction in the soybean-livestock integration of milk in clayey latosol with direct seeding and scarification. Brazilian Journal of Soil Science, 37, 1699-1708. https://doi.org/10.1590/S0100-068320 1300060002

Loss, A., Pereira, M. G., Giácomo, S. G., Perin, A., \& Aanjos, L. H. C. dos. (2011). Agregação, carbono e nitrogênio em agregados do solo sob plantio direto com integração lavoura-pecuária. Pesquisa Agropecuária Brasileira, 46(10), 1269-1276. https://doi.org/10.1590/S0100-204X2011001000022

Marahatta, S., Sah, S. K., Mac Donald, A., Timilnisa, J., \& Devkota, K. P. (2014). Influence of conservation agriculture practices on physical and chemical properties of soil. International Journal of Advanced Research, 2, 43-52. Retrive from http://www.journalijar.com/uploads/638_IJAR-4425.pdf

Melo, D., Nóbrega, L. H. P., Gnoatto, E., Marchetti, I., \& Lenz, A. M. (2014). Compactação do solo em áreas de produção de silagem de planta inteira de milho sob o sistema de plantio direto. XLIII Congresso Brasileiro de Engenharia Agrícola—CONBEA 2014, Campo Grande, MS.

Millington, W. A., Misiewicz, P. A., Dickin, E. T., White, D. R., \& Godwin, R. J. (2016). An investigation into the effect of soil compaction and tillage on plant growth and yield of winter barley (Hordeum vulgare L.). Written for presentation at the 2016 ASABE Annual International Meeting Sponsored by ASABE Orlando, Florida, 17-20 July.

Mottin, M. C. (2016). Efeito de plantas de cobertura cultivadas no inverno nas propriedades físicas do solo e na produtividade de soja e milho em sucessão (p. 49, Dissertação, Mestrado em Agronomia, Universidade Estadual do Oeste do Paraná, Marechal Cândido Rondon, PR, Brasil).

Reichert, J. M., Kaiser, D. R., Reinert, D. J., \& Riquelme, U. F. B. (2009a). Variação temporal de propriedades físicas do solo e crescimento radicular de feijoeiro em quatro sistemas de manejo. Pesquisa Agropecuária Brasileira, 44, 310-319. https://doi.org/10.1590/S0100-204X2009000300013

Reichert, J. M., Suzuki, L. E. A., Reinert, D. J., Horn, R., \& Hakansson, I. (2009b). Reference bulk density and critical degree-of-compactness for no-till crop production in subtropical highly weathered soils. Soil \& Tillage Research, 102, 242-254. https://doi.org/10.106/j.still.2008.07.002

Rosset, J. S. (2015). Caracterização da matéria orgânica, atributos químicos e físicos do solo sob diferentes sistemas de manejo na região Oeste do Paraná (p. 90, Tese, Doutorado em Agronomia, Universidade Estadual do Oeste do Paraná, Marechal Cândido Rondon, PR, Brasil).

Santos, H. B. (2006). Sistema brasileiro de classificação de solos (2nd ed.). EMBRAPA, Brasília, DF.

Scolari, D. D. G. (2006). Produção agrícola mundial: O potencial do Brasil. Visão progressista do agronegócio brasileiro (pp. 9-86). Fundação Milton Campos, Brasília, DF. Retrieved from https://www.alice.cnptia. embrapa.br/alice/handle/doc/417182

Secco, D., Ros, C. O., Secco, J. K., \& Fiorin, J. E. (2005). Physical attributes and crop productivity in an Argiloso Red Latosol under different management systems. Brazilian Journal of Soil Science, 29, 407-414. https://doi.org/10.1590/S0100-06832005000300011

Seidel, E. P., Gerhardt, I. F. S., Castagnara, D. D., \& Neres, M. A. (2014). Efeito da época e sistema de semeadura da Brachiaria brizantha em consórcio com o milho, sobre os componentes de produção e propriedades físicas do solo. Semina: Ciências Agrárias, 35(1), 55-66. https://doi.org/10.5433/1679-0359

Silva, A. P. da, Tormena, C. A., Junior, M. S. D., Imhoff, S., \& Klein, V. A. (2016). Indicadores de qualidade física do solo. In Q. J. van Lier (Ed.), Física do solo (1st ed., $2^{\circ}$ Reimpressão, pp. 241-282). Sociedade Brasileira de Ciência do Solo, Viçosa, MG.

Silva, M. A. (2007). Root development of bean, soybean and corn crops, under different soil management, irrigated by central pivot (Doctoral thesis, Postgraduate Program in Irrigation and Drainage, Paulista State University Júlio de Mesquita Filho, Botucatu, SP, Brasil).

Stolf, R. (1991). Theory and experimental test of formulas of transformation of the penetrometer data of impact in soil resistance. Brazilian Journal of Soil Science, 15, 229-235. 
Voorhees, W. B., Johnson, J. F., Randall, G. W., \& Nelson, W. W. (1989). Corn Growth and Yield as Affected by Surface and Subsoil Compaction. Agronomy Journal, 81, 294-303. https://doi.org/10.2134/agronj1989.000 $21962008100020031 x$

\section{Copyrights}

Copyright for this article is retained by the author(s), with first publication rights granted to the journal.

This is an open-access article distributed under the terms and conditions of the Creative Commons Attribution license (http://creativecommons.org/licenses/by/4.0/). 